\title{
"I WILL WRITE THAT I NO LONGER RESPECT MY COLLEAGUES". PARTIES IN G.P. FEDOTOV'S CONFLICT WITH THE BOARD OF ST. SERGIUS ORTHODOX INSTITUTE IN PARIS (1939)
}

\author{
Anton A. Voytenko \\ Center for Egyptological Studies, Russian Academy of Sciences, Moscow, Russian Federation
}

\begin{abstract}
Historians, who study the history of Post-Revolutionary Russian emigration, the history of St. Sergius Orthodox Institute in Paris, and the biography of Georgy P. Fedotov, are well aware of G.P. Fedotov's conflict with the Board of this Theological Institute in 1939. For a long time, researchers had only one basic source on these events at their disposal. It is a biographical sketch by G. Fedotov's wife, which precedes the first volume of his article's collection published in Ymca-Press publishing house. However, a considerable number of documents (mainly from the Bakhmetiev archive, Columbia University, USA) have been published over the past several decades. They allow considering the conflict in more detail. The author of the article makes an attempt to identify parties of the conflict, their goals and objectives. From his point of view, the published documents point to the complicated nature of the conflict. It had at least two levels: 1) the conflict of G. Fedotov with rector of the Institute, Metropolitan Eulogy (Georgievsky), which was quite quickly resolved, and 2) the conflict of G. Fedotov with some members of the Board who sought his dismissal from the Institute. In contrast to the events of 1936, G. Fedotov was strongly supported by Nikolay Berdyaev and G. Fedotov's friends from the organisation Pravoslavnoye Delo (mother Maria (Skobtsova), Fedor Pianov and others). It can be supposed with a high degree of probability that the main opponent of G. Fedotov at the Institute was Father Georges (Florovsky). In conformity with indirect data, it can also be assumed that Florovsky was supported by Anton Kartashev and Vasily Zenkovsky. Some members of the Board, father Sergius (Bulgakov), Nikolai Afanasyev, archimandrite Cassian (Bezobrazov), probably remained neutral. The position of the rest members of the Board is still unclear. However, it is clear that no one of the Board supported G. Fedotov. G. Fedotov called the deed of their colleagues dishonest. This conflict can be really described as a conflict of Georgy Fedotov with all the Board of the Institute, and the published documents confirm this point of view.

Key words: Georgy Petrovich Fedotov; Fr. Georges (Florovsky); Fr. Sergius (Bulgakov); Metropolitan Eulogy (Georgievsky); St. Sergius Orthodox Institute in Paris; Bakhmetiev archive, Columbia University.

Citation. Voytenko A.A. "I Will Write That I no Longer Respect My Colleagues". Parties in G.P. Fedotov's Conflict with the Board of St. Sergius Orthodox Institute in Paris (1939). Vestnik Volgogradskogo gosudarstvennogo universiteta. Serija 4, Istorija. Regionovedenie. Mezhdunarodnye otnoshenija [Science Journal of Volgograd State University. History. Area Studies. International Relations], 2017, vol. 22, no. 4, pp. 56-65. (in Russian). DOI: https://doi.org/10.15688/jvolsu4.2017.4.6
\end{abstract}

\section{«НАПИШУ, ЧТО Я ОТНЫНЕ НЕ УВАЖАЮ СВОИХ КОЛЛЕГ». ДЕЙСТВУЮЩИЕ ЛИЦА КОНФЛИКТА Г.П. ФЕДОТОВА С ПРАВЛЕНИЕМ БОГОСЛОВСКОГО ИНСТИТУТА В ПАРИЖЕ (1939)}

\author{
Антон Анатольевич Войтенко
}

Центр египтологических исследований Российской академии наук, г. Москва, Российская Федерация 
Аннотация. Всем, кто занимается историей русской эмиграции, историей Богословского института в Париже и биографией Георгия Петровича Федотова, хорошо известен его конфликт с Правлением Богословского институга в 1939 году. Долгое время почти единственным источником о нем был биографический очерк жены Федотова, Елены Николаевны, предваряющий первый том его сочинений, который вышел в издательстве «Ymca-Press». Однако за последние десятилетия был издан значительный фонд архивных документов (главным образом из Бахметьевского архива Колумбийского университета, США), который позволяет взглянуть на этот конфликт более детально. Автором данной статьи предпринято исследование по выявлению «сторон» конфликта, их целей и задач. С его точки зрения, опубликованные документы говорят о сложном характере конфликта, где было, как минимум, два уровня: конфликт Г.П. Федотова с митр. Евлогием (который довольно быстро был разрешен) и конфликт Федотова с частью профессоров из Правления, которые добивались его увольнения из Богословского институга. В отличие от событий 1936 г., в этот раз на стороне Федотова решительно выступили Н.А. Бердяев, друзья и соратники Федотова по организации «Православное дело» (м. Мария (Скобцова), Ф.Т. Пьянов и др.). На основании опубликованных материалов можно с большой степенью вероятности предположить, что главным противником Федотова был о. Георгий (Флоровский). По косвенным данным можно полагать, что Флоровского поддержали А.В. Карташев и В.В. Зеньковский. Часть членов Правления (о. Сергий (Булгаков), Н.Н. Афанасьев, о. Кассиан (Безобразов)), вероятно, сохраняли нейтралитет. Позиция остальных членов Правления остается пока не известной. Однако совершенно ясно, что никто из Правления не поддержал Г.П. Федотова. Сам Федотов называл поведение своих коллег бесчестным. Поэтому данный конфликт можно квалифицировать как конфликт Г.П. Федотова со всем Правлением Богословского института, и опубликованные на сегодняшний день документы это подтверждают.

Ключевые слова: Георгий Петрович Федотов, о. Георгий (Флоровский), о. Сергий (Булгаков), митр. Евлогий (Георгиевский), Богословский институг в Париже, Бахметьевский архив (Колумбийский университет, США).

Цитирование. Войтенко А. А. «Напишу, что я отныне не уважаю своих коллег». Действующие лица конфликта Г.П. Федотова с Правлением Богословского института в Париже (1939) // Вестник Волгоградского государственного университета. Серия 4, История. Регионоведение. Международные отношения. - 2017. T. 22, № 4. - C. 56-65. - DOI: https://doi.org/10.15688/jvolsu4.2017.4.6

Как нам представляется, не будет большим преувеличением утверждать, что подлинным интеллектуальным центром русской эмиграции «первой волны» с середины 20-х по конец 30-х гг. ХХ в. был Париж. Именно здесь в это время присутствовал почти весь спектр политических и интеллектуальных течений русской эмиграции - от правомонархических до социалистических, не принявших новую, большевистскую власть в России. Именно здесь в это время находились многие знаменитые русские философы и писатели, политические деятели и публицисты. И именно в Париже в 1925 г. возник Свято-Сергиевский православный богословский институт, давший имя целому направлению богословской мысли («парижская школа»), который в последующие пятнадцать лет пережил свой расцвет. В составе преподавателей института оказалась целая плеяда известных впоследствии богословов, философов, историков церкви, таких как о. Сергий (Булгаков), о. Георгий (Флоровский), о. Кассиан (Безобразов) (впоследствии - епископ), В.В. Зеньковский (впоследствии - священник), А.В. Карташев, архим. Киприан (Керн), Б.П. Вышеславцев и др.
В этот же период в Богословском институте преподавал и известный религиозный мыслитель, историк и публицист Георгий Петрович Федотов. Однако, как это ни странно, история Богословского института в Париже до сих пор еще не написана, поэтому выбранная нами тема, связанная с конфликтом Г.П. Федотова с другими профессорами, входившими в Правление Богословского института, представляется актуальной.

Конфликт вспыхнул в самом начале 1939 г., продлился без малого полгода и закончился весьма паллиативно и невнятно: в связи с нападками на институт со стороны правомонархического лагеря после нескольких публицистических статей Федотова от него потребовали прекратить публицистическую деятельность и вынесли порицание. Федотов посчитал порицание несправедливым и отказал требованиям Правления института. Возникла угроза его исключения. В результате исключен Федотов не был, но и порицание с него не сняли (чего он активно добивался). Конфликт, безусловно, был существенный вехой в биографии Г.П. Федотова, оставил значительной след в его душе и сподвигнул его на попытку этико- 
философского осмысления действий своих «визави». По своей природе данный конфликт, безусловно, выходит за пределы конкретных причин и следствий, поскольку в его основе лежал один «архетипический» вопрос: до какой степени может быть ограничена свобода публичных высказываний (или действий) члена интеллектуальной корпорации, если она входит в противоречие с принципами корпоративной этики (подлинными или мнимыми)? Однако это не отменяет исследования конкретно-исторической коллизии самого конфликта, тем более что изданные на сегодняшний момент источники вполне позволяют это сделать.

Публикация документов, связанных с конфликтом (в основном это переписка Г.П. Федотова со своими сторонниками и противниками), предпринималась неоднократно. Речь идет о документах, хранящихся главным образом в фонде Федотова в Бахметьевском архиве (Колумбийский университет, США). Часть писем была опубликована еще в 90-х гг. прошлого века Д. Бон в журнале «Звезда», шесть лет спустя последовала публикация Н.А. Струве, а затем - С.С. Бычкова [7; 9; 11]. Наконец наиболее полный корпус документов по этой теме был издан в 2008 г. в 12-м томе собрания сочинений Г.П. Федотова [3]. К сожалению, неопубликованным (или утраченным) оказался ряд важных свидетельств: самые первые письма Федотова к митр. Евлогию и о. Сергию (Булгакову), составленные почти сразу после получения официальной выписки из постановления Правления и писем обоих адресатов к нему. Письмо к о. Сергию, судя по всему, было адресовано не только ему, но и всему Правлению, где Федотов (судя по сохранившимся цитатам и намекам) давал нелестные характеристики своим коллегам. О наличии этих писем есть указания в переписке (есть даже некоторые цитаты из письма Федотова о. Сергию) [3, с. 284, 289, 376]. Другим важным источником могут быть письма Е.Н. Федотовой к мужу, написанные в период конфликта. Как хорошо известно, ко времени начала конфликта Федотов находился в Англии, получив полугодовой академический отпуск, и жена, оставшаяся в Париже, была, безо всякого преувеличения, его глазами и ушами: в своих письмах к жене он дает ей различные поручения, спрашивает ее мнения, советуется или спорит. Од- нако судьба писем Е.Н. Федотовой к мужу нам не ясна: среди известных нам опубликованных документов их нет.

Внимание конфликту 1939 г. уделялось как в общих биографических очерках о Г.П. Федотове, так и в отдельных статьях и предисловиях к публикациям документов. О конфликте пишут Е.Н. Федотова, о. Александр Мень, Д. Бон, Н.А. Струве, С.С. Бычков [2, с. 35-39; 4 , c. $470-475 ; 7$, c. $117-119 ; 8$, c. $23-26$; 9, c. $186-$ $187 ; 16$, c. XXV-XXVII]. Отдельным аспектам конфликта были посвящены статьи А.А. Галямичевой и А.В. Антощенко $[1 ; 5]$. Однако в этих публикациях (да и то не во всех) отражена лишь внешняя канва событий: как правило, очень пунктирно и в общих чертах. В то же время опубликованные материалы позволяют рассмотреть этот конфликт гораздо глубже. В одном из своих писем к Федотову о. Сергий (Булгаков) писал, что у «распри» оказались «стороны» [3, с. 377]. Анализу этих «сторон» и их позиций и посвящена данная статья. Как это ни удивительно, но при довольно массивном корпусе изданных источников этот анализ пока не был предпринят.

Данные источников ясно показывают, что конфликт имел два уровня. Первый - конфликт Федотова с митр. Евлогием, что послужило его внешней стороной. Второй, на что намекал уже Н.А. Струве [9, с. 187], - конфликт Федотова с частью профессорского состава, которая хотела воспользоваться этой ситуацией и либо принудить Федотова к отказу от политической публицистики, либо, при удачном стечении обстоятельств, добиться его увольнения из института. Именно этот, второй уровень конфликта, на наш взгляд, и был главным.

Однако рассмотрим сначала поведение митр. Евлогия. Как известно, поводом к конфликту послужила статья Ю. Семенова в правоэмигрантской газете «Возрождение» под названием «Против “сатанинского нашествия"》 (от 3 февраля 1939 г.) с нападками на некоторые фразы из статьи Г.П. Федотова «Торопитесь!». $\mathrm{Bce}$, кто писал о начале конфликта, почему-то упускали из вида то обстоятельство, что нападки именно на эту статью Федотова с цитатой, послужившей впоследствии «камнем преткновения», не новы. Критику именно этой цитаты Ю. Семенов предпринял ранее, в статье «Раз- 
гром большевиков и “сверх-христиане”» (номер «Возрождения» от 27 января того же года), где, помимо прочего, писал: «Конечно, профессор будет оборонять [т. е. поддерживать СССР в случае войны с Германий], хотя бы из Парижа. У него ведь есть слушатели, студенты Богословского Института в Париже, которые, восприняв “сверх-христианский” идеал Интернационала, проникнутся советским патриотизмом сталинской “империи” и будуть действенно ее оборонять» [14, с. 1]. Статья не вызвала у митрополита столь бурной реакции (хотя она также фигурировала в выписке из протокола заседания Правления от 8 февраля). Зато статья от 3 февраля послужила поводом для созыва Правления, вынесения Федотову порицания и фактически предьявления ему ультиматума: либо уйти из института, либо прекратить печатать политическую публицистику.

Что же так переполошило митрополита? Публикаторы документов (Н.А. Струве, С.С. Бычков) дают лишь один абзац из этой статьи. Но, чтобы понять мотивы действий владыки, следует проанализировать ее полный текст. В статье Семенов подробно разбирает речь Гитлера, посвященную причинам вмешательства Германии в гражданскую войну в Испании. Помимо прочего, он касается и внутриполитической части этой речи. И вот тут начинается самое интересное. Семенов останавливается на церковной политике Гитлера и на его борьбе «с частью католического и протестантского духовенства». Далее он продолжает свою мысль так: «Не с религией и не с церковью борется фюрер, а с ослепленными и развращенными служителями церкви. Религия непогрешима, и церковь, несмотря на возможные случайные ее ошибки в ее сношениях со светскими учреждениями, державна в своей внутренней, духовной жизни, и всякое восстание против нее в конце концов завершается неудачей. Но церковные служители такие же люди, как и все прочие, они подчиняются тем же законам природы и человеческим, как и все остальные люди. Им свойственны те же заблуждения, которыя характерны для данного времени». Далее следует уже неоднократно цитируемый пассаж о некоторых профессорах православного Богословского института, «которые именуют идеал марксистского интернационала “сверх-христианским”” или призыва- ют на проповеди «преклониться перед мировым еврейством», после чего Семенов опять возвращается к церковной политике Гитлера: «...фюрер не допускает критики законов страны с кафедры проповедника. Все нарушители законов должны быть караемы. <..> Хитлер гневно обрушился на священнослужителей “педерастов" (так он их назвал несколько раз), которых он обещал “истребить”, как он пять лет тому назад истребил таких же порочных людей в своей партии. Как известно, интернационал развратников, поклонников разных чекисток Пассионарий или предающихся иным порокам так же влиятелен, как марксистские, масонские и другие. <...> Вот этих людей Хитлер обещает “истреблять” беспощадно. Почему-то в Германии они нашли себе приют в духовном сословии рядом с выдающимися учеными богословами и с безупречными церковными деятелями, возбуждающими всеобщее преклонение святостью своей жизни. Последних Хитлер освобождает от ядовитых плевел». После чего Семенов подводит итог: «Страны, общественные и политические течения, не способные верить, остаются на задворках международной политики, лишенные всякой инициативы, в то время как политику делают те, кто "кристаллизуются в борьбе с сатанинским нашествием". <...> Зарубежная Россия, давно предсказавшая неизбежность международной “кристаллизации в борьбе", может теперь в спокойной уверенности ждать того близкого дня, когда она скажет: встаньте, суд идет!» [13, c. 1]. Если вспомнить, что после прихода Гитлера к власти в Германии все верные митр. Евлогию приходы были переданы карловацкому синоду (см.: [10, с. 203]) (и митрополит, безусловно, об этом знал), то статья Семенова выглядит как угроза и слегка скрытый шантаж. Еще более очевидным это становится, если учесть тот факт, что в Париже в это время гостил глава карловацкого синода, митр. Анастасий (Грибановский).

В начале 1939 г. вряд ли у кого-то были сомнения в неизбежности войны, а также в том, что правомонархические эмигрантские круги в Париже уже были нацелены прыгнуть в нацистский обоз (если слегка перефразировать выражение В. Яновского (см.: [17, с. 54]). Слегка завуалированные угрозы конфискаций со стороны Семенова в случае занятия Гитлером 
Парижа, вспыльчивость митрополита (на что намекает м. Мария (Скобцова) [3, с. 278-279]), как кажется, предполагают именно такую реакцию владыки. Остается пока непонятным, кто и при каких обстоятельствах ознакомил митрополита с этой статьей Семенова в «Возрождении». Впрочем, есть и другая возможная причина такой болезненной реакции митрополита. В письме к Федотову А.Д. Семенов ТяньШанский, в то время студент института, формулирует ее так: «Дело, конечно, не в левизне убеждений, а в том, что Вы неосторожно, слишком задорными и парадоксальными положениями задевали и отчасти оскорбляли чувства большинства эмиграции, которая является и большинством верующих нашей епархии. С такой точки зрения Ваша слишком боевая позиция представляла несомненную опасность и для Института, который, будучи свободным и независмым от политики, в какой-то мере должен считаться с большинством паствы М. Евлогия, не давая повода к ненужным конфликтам» [3, с. 300-301]. Возможно, было бы неверным утверждать (у нас нет для этого данных), что бульшая часть русской эмиграции в Париже полностью разделяла взгляды «Возрождения», стоявшего в то время на откровенно пронацистских позициях, но людей с пореволюционными взглядами было, вероятно, в приходах евлогиан не так много. Однако, на наш взгляд, вероятность опасности брожения в приходах из-за данной статьи в «Возрождении» была невелика.

Митр. Евлогий предпринял несколько шагов по устранению напряженности. В редакцию «Возрождения» было направлено письмо студентов института, где, в частности, указывалось, что «появившаяся в... газете от 3 февраля с. г. передовая статья стремится совершенно неосновательно приписать Богословскому Институту в его целом мнения отдельных профессоров, высказываемые ими вне стен Института и не в порядке преподавания», а «Институт не является политическим учреждением, и его профессора в своих лекциях держатся строго научного и церковнаго направления, не касаясь политики» [12, с. 3]. 11 февраля сам митр. Евлогий пишет хорошо известное окрытое письмо главному редактору газеты, где, в частности, сообщает: «Что касается левых политичес- ких выступлений в печати профессора Г.П. Федотова, то я понимаю, что они не могли не вызвать протеста со стороны национально мыслящих людей. Такое же отрицательное отношение к этим выступлениям выразил и сам Богословский Институт, и его профессора, и студенты. Но ему трудно брать на себя ответственность за всякое выступление своего профессора вне Института в его частной литературной деятельности» [6, c. 7]. Семенов в своем ответе в целом благосклонно отреагировал на письмо митрополита, давая понять, что он удовлетворен и продолжения кампании не будет [15]. Таким образом, можно считать, что после 17 февраля конфликтная ситуация между Богословским институтом и главным редактором «Возрождения» была улажена. Правда, есть свидетельство м. Марии, что позже митрополит жалел о своем письме Семенову, поскольку после него это дело получило еще бульшую огласку [3, с. 337].

Теперь посмотрим, как развивалась ситуация между Федотовым и митрополитом. 10 февраля, то есть накануне своего письма Семенову, митрополит посылает Федотову письмо, где напоминает ему об истории с публикацией статьи «Пассионария» трехлетней давности, называет слова о «сверх-христианской жертвенности» интернационала кощунством, сообщает о вынесенном ему Правлением порицании и ставит ультиматум: прекратить заниматься политической публицистикой, поскольку это занятие несовместимо с работой в институте [3, с. 276-277]. Федотов отвечает ему, но о содержании этого ответа мы можем судить только по его письму к жене от 18 февраля: «Письмо к митрополиту на 4 листах, очень кроткое, но решительное. Вполне в твоем духе. Я доказываю, почему я не могу подчиниться, что значит революционная интеллигенция для Церкви и в чем я вижу свое церковное служение. Прошу решать его по своей оценке, не считаясь с моей личностью» [3, с. 289]. В ответном письме от 21 февраля (заметим, что реакция Семенова уже была известна) митрополит фактически дезавуирует многие положения своего предыдущего послания. Он просит прощения у Федотова за резкий тон своего первого письма, просит его не уходить из института и впредь быть аккуратнее в сво- 
их публицистических выступлениях, чтобы они не давали повода для нападок на институт [3, с. 304-305]. Таким образом, после 21 февраля конфликт между митрополитом и Федотовым можно считать исчерпанным. Надо сказать, что немалую роль в его разрешении сыграла м. Мария (Скобцова), которая, добившись аудиенции у владыки, лично убедила его прочесть «крамольные» статьи Федотова, из-за которых вспыхнул конфликт, и убедиться, что в материалах «Возрождения» их смысл был искажен [3, с. 290-291].

Казалось бы, после этого конфликт должен был быстро разрешиться, но он продлился еще несколько месяцев - примерно до начала или середины июня. И здесь стоит вспомнить о другом, более серьезном его уровне. Для начала приведем замечание Н.А. Струве: «В решении Института сыграл, с одной стороны, страх за его будущее, с другой, и внутрипрофессорские интриги, в которых был, судя по всему, повинен о. Георгий Флоровский» [9, с. 187]. Чтобы понять суть ситуации, необходимо вернуться на пятнадцать лет назад, к тому моменту, когда Г.П. Федотов устроился на работу в Богословский институт. Хорошо известно, что инициатива исходила не от него: в институт его настойчиво приглашали. Принял он приглашение главным образом под давлением обстоятельств: в Сорбонне места ему не нашлось, а публицистика достаточного «экзистенц-минимума» не давала. В институте Федотов держался обособленно, и ни с кем, кроме как с К.В. Мочульским, преподававшим также в Сорбонне, он близко не сходился [7, с. 118]. Основные его соратники и единомышленики находились в других местах - в Кламаре (Н.А. Бердяев) и на улице Лурмель, где располагалась «штабквартира» организации «Православное дело», куда помимо Федотова входили м. Мария (Скобцова), И.И. Фондаминский, Ф.Т. Пьянов и уже упомянутый нами К.В. Мочульский. Именно эти люди и будут составлять «сторону Федотова» в конфликте, именно от них (помимо жены) он будет получать необходимую информацию, советоваться и совместно вырабатывать стратегию и тактику поведения.

Кто составлял лагерь его противников? Сам Федотов говорит о нем неопределенно («Богословский институт», «Правление», «кол- леги») или просто употребляет местоимение «они». Но один раз он упоминает о двух половинах Правления, где его противники, вероятно, составляют одну из них [3, с. 330]. Митр. Евлогий в доверительном разговоре с м. Марией (Скобцовой) подтвержает ее мнение о существовании в институте некой группы, которая добивается ухода Федотова [3, с. 356]. Таким образом, мы можем говорить о группе профессоров в Правлении, которые хотели воспользоваться ситуацией для того, чтобы осуществить свой замысел. Кто же входил в эту «группу»? Вряд ли будет ошибкой предположить с большой долей вероятности, что ее идейным вдохновителем и неформальным лидером был о. Георгий (Флоровский). О личной неприязни друг к другу двух «Г. Ф.» русской эмиграции хорошо известно. Однако, насколько мы знаем, до сих пор не изучен вопрос, имела ли она только «человеческое измерение», то есть все ли можно объяснить чисто психологическими мотивами, или за ней в том числе скрывалось неприятие идейных позиций друг друга: различные взгляды на христианство и его роль в современном мире.

На Флоровского как на своего противника прямо и недвусмысленно указывает и Федотов в своей переписке: «Там [то есть в Богословском институте] есть такой центр сопротивления, как Флоровский. Если он поставит вопрос так: или он или я, митрополит [Евлогий] его предпочтет» [3, с. 307]. Федотов хорошо отдает себе отчет в том, что имеет дело с влиятельным и идейным неприятелем. В одном из писем он указывает, что его уход из Правления означает «отдать все Флоровскому», а «о. Сергий [Булгаков] и рта раскрыть не посмеет» [3, с. 309]. О влиянии Флоровского в Правлении мы находим свидетельство и в другом месте: в качестве варианта примирения Федотов предлагает снятие резолюции о вынесении ему порицания, но так, чтобы об этом не знал Флоровский [3, с. 307]. В одном из писем к жене он роняет такую фразу: «Правление, конечно, верит в то, что нами организуется мировой комплот против него, и если страх действует на Зеньковских, то на бесноватых он не действует» [3, с. 330]. С большой долей уверенности можно предполагать, что под «бесноватыми» Федотов имеет в виду прежде всего Флоровского, а контекст фразы 
(речь идет о переговорах Е.Н. Федотовой с П. Андерсоном) предполагает его убежденность в том, что Флоровского не остановит даже страх финансовых проблем для института в связи с «Федотовским делом». Наконец, в мемуарах В. Яновского есть еще одно, очень интересное свидетельство, связанное со статьей Федотова о Долорес Ибарури: «...один профессор православного института, где преподавал Георгий Петрович, некая светлая личность, потребовала исключения Федотова как “тайного масона и марксиста"» [17, с. 53]. Кем была эта «светлая личность» - нам неизвестно, но возможность того, что Яновский в данном случае имеет в виду Флоровского (по каким-то причинам не называя его по имени), исключать нельзя. Как нельзя исключать и того, что речь идет не о полемике вокруг статьи «Пассионария», а о событиях 1939 г., поскольку далее Яновский пишет, что «потасовка такого рода стоила Федотову много внутренних сил» $[17$, с. 53$]$.

Таким образом, активное участие Флоровского в конфликте 1939 г. вряд ли подлежит сомнению. Кто еще входил в «группу»? По некоторым имеющимся свидетельствам, Флоровского поддержал А.В. Карташев, который, так же как и о. Георгий, на тот момент входил в состав Правления. Намеки на это содержатся в письме м. Марии Федотову от 6 апреля. Она, в частности, пишет: «У меня лично впечатление от всех разговоров, что кроме Флоровского и Карташева, а м. б., даже и они в последнем счете, - все готовы на любые уступки, лишь бы как-нибудь сохранить лицо». И далее: «И хотя при всеобщей истерике можно ждать покаянных воплей и от Карташева, и от Флоровского...» [3, с. 337]. Из переписки Федотова известно, что у него с Карташевым были серьезные расхождения по вопросу библейской критики, в одном из писем он называет Карташева и Сове предателями [3, с. 324].

Наконец, еще одним членом «группы» или тем, кто к ней примкнул, мог быть В.В. Зеньковский. В самом начале конфликта Зеньковский посылает Федотову письмо, где просит его прекратить писать политическую публицистику, но не уходить из института [3, с. 295]. Федотов не верит в его искренность, о чем пишет жене [3, с. 302]. Далее следует совместное с Флоровским письмо Зеньковского к Федотову, из которого четко видно, что ситуация вокруг статьи «Торопитесь!» и нападки на нее в «Возрождении» являются непричиной конфликта, а его поводом: «Вы глубоко ошибаетесь, если думаете, что на осуждение членов Правления о Вашей публицистической деятельности имели влияние выпады “Возрождения". Эти выпады были поводом к тому, чтобы выразить наше отношение к Вашим публицистическим выступлениям, которые нас давно тревожат» [3, c. 317]. Ясно, что обоих уже давно раздражала политическая публицистика Федотова и они, как минимум, хотели ее ограничить. Интересно и свидетельство жены Федотова. Она пишет, что Зеньковский был единственным членом Правления, который прочел статью Федотова «Торопитесь!» и мог бы указать на то, что, прежде чем судить статью, ее надо бы прочесть, однако он этого не сделал и предпочел присоединиться к порицанию [16, с. XXV]. В одном из писем к жене Федотов характеризует Зеньковского как человека рассудительного и не склонного к эмоциям, но в то же время достаточно конъюнктурного: «Зеньковский меня удивил своей поспешностью. Я не думаю, чтобы этот человек способен поддаваться аффектам. Он естественно клонится, куда ветер дует, но обыкновенно не теряет меры, стараясь сохранить и в подлости остаток благородства. <...> В метеорологии мне с ним не сравниться» [3, с. 368-369]. Суммируя все вместе, можно полагать, что позиция Зеньковского в конфликте (точнее, ее изменения) выражали изменения настроений в Правлении, что немаловажно при анализе развития конфликта.

Можно с большой долей вероятности указать на трех человек, которые сохраняли нейтралитет. Прежде всего это о. Сергий (Булгаков). М. Мария «из третьих рук» сообщает Федотову, что на Правлении от 8 февраля о. Сергий пытался возразить митрополиту, но последний на него накричал [3, с. 278]. Напомним, что о. Сергий также стал предметом нападок в статье Семенова от 3 февраля, и митр. Евлогий был вынужден в своем ответном письме к Семенову разьяснять позицию о. Сергия. В то же время о. Сергий в своем первом письме к Федотову после начала конфликта советует ему оставить занятия политической публицистикой [3, с. 273-276]. Отношение Федотова к о. Сергию (как это 
явствует из писем) было неоднозначным: от симпатии до достаточно резких выпадов против него. Главным образом Федотову претила его пассивность и нерешительность, когда надо было принимать принципиальные решения (вспомним его замечание о том, что стоит ему уйти из Правления, и о. Сергий рта раскрыть не посмеет). Однако вскоре о. Сергий «выпал» из конфликта по объективным причинам: у него пошатнулось здоровье, он перенес операцию и послеоперационную реабилитацию. Впоследствии о. Сергий старался примирить обе стороны. Вторым человеком, сохранявшим нейтралитет, вероятнее всего, был преподаватель канонического права Н.Н. Афанасьев. В своем ответном письме к о. Сергию Федотов пишет, что его фраза о неуважении к коллегам не касается ни о. Сергия, ни «Ник. Ник.», то есть Афанасьева [3, с. 323]. Третьим человеком был архим. Кассиан (Безобразов), с которым Федотов был знаком еще со студенческой скамьи. В письме (не датированном) к о. Сергию (Булгакову) Федотов пишет: «... я понял, что, во-первых, я могу считать вас с отцом Кассианом своими друзьями, и до известной степени единомышленниками, а во-вторых, что все остальные в Институте против меня» [3, с. 359].

Позиция остальных членов Правления до конца не ясна. Д. Бон сообщает, что в Правление Богословского института, помимо уже перечисленных нами преподавателей, входили И. Лаговский, В. Ильин, Н. Лосский, Б. Вышеславцев, Л. Зандер, Н. Кюльман, П. Ковалевский, П. Честноков, архим. Киприан (Керн), Б. Сове, П. Лютов [7, с. 118]. Но сведениями, кто именно из них входил в Правление в первой половине 1939 г., мы не располагаем. Федотов был убежден, что предложение митрополита было поддержано большинством Правления на заседании 3 февраля [3, с. 286]. Это же подтверждается и в письме о. Сергия от 9 февраля, где он пишет Федотову: «Разногласия по существу вопроса между нами не оказалось». Но далее замечает: «Отделяться же ради лишь словесных оттенков в особое мнение и тем давать повод для новых вредительских действий на эту тему я, как и некоторые другие (курсив наш. - A. В.), не счел для себя позволительным. Поэтому самый текст резолюции не должен быть Вами принят a la lettre [то есть буквально], по крайней мере для отдельных членов правления, а лишь как общая формула» [3, с. 274-275]. Есть и еще одно интересное замечание Федотова: свою опасность ухода из Правления он объясняет тем, что, обладая правом veto, он может «предупреждать некоторые позорные решения» [3, с. 309]. Вероятно, правом veto обладал не только Федотов, но и другие члены Правления, но никто из них не воспользовался им, чтобы отклонить резолюцию на заседании 3 февраля и ее подтверждение на заседании 30 марта. Таким образом, можно полагать, что в Правлении помимо «группы», о которой речь уже шла, были нейтральные или даже сочувствующие Федотову профессора, но никто из них в конечном итоге не осмелился пойти против мнения 〈группы» и митрополита 3 февраля и не решился отменить постановление на заседании 30 марта.

Перейдем к заключению. На основе анализа переписки можно считать установленным тот факт, что конфликт Г.П. Федотова с Правлением Богословского института имел два уровня. Первый его уровень составлял конфликт Г.П. Федотова с митр. Евлогием, который не носил глубокого характера и, скорее, был обусловлен привходящими обстоятельствами, причины которых следует искать в политике главного редактора «Возрождения» Ю. Семенова на фоне сложной внутри- и внешнеполитической обстановки в Европе конца 30-х гг. XX века. Второй, более глубокий уровень заключался в том, что на поверхность вышли противоречия Г.П. Федотова с частью профессоров института, которая в переписке обозначена как «группа». С большой степенью уверенности можно утверждать, что идейным вдохновителем этой «группы» был о. Георгий (Флоровский). Кто еще примыкал к «группе» - точно не известно, но по косвенным данным можно предположить, что Флоровского поддерживали А.В. Карташев и, вероятно, В.В. Зеньковский. Сочувственную Г.П. Федотову или же нейтральную позицию могли занимать о. Сергий (Булгаков), Н.Н. Афанасьев и о. Кассиан (Безобразов), однако они не решились выступить в защиту Федотова на двух заседаниях Правления (кроме не имевшей никакого практичекого значения попытки о. Сергия (Булгакова) на заседании от 3 февраля). Позиция других членов Правления не 
ясна. Однако очевидно, что они также поддержали резолюцию, выносящую Федотову порицание за его публицистическую деятельность, где он выступает не как профессор института, а как частное лицо. Федотов, как это видно из анализа его писем, полагал, что возникшее разногласие имеет отношение не к отдельным профессорам института, а ко всем членам Правления. На основании проведенного анализа нам представляется справедливым утверждать, что конфлит Федотова был конфликтом со всем Правлением Богословского института, а не с какой-то его частью. Тем не менее сразу же после начала конфликта у Г.П. Федотова образовалась группа единомышленников, куда помимо его жены входили идейно близкие ему члены организации «Православное дело» (м. Мария (Скобцова), К.В. Мочульский, Ф.Т. Пьянов и др.), а также Н.А. Бердяев. Эта группа оказывала Федотову моральную и информационную поддержку и в значительной степени определяла стратегию и тактику его поведения во время конфликта. Этапы протекания конфликта и его итоги требуют отдельного исследования, эти сюжеты выходят за рамки темы, обозначенной нами в статье.

\section{СПИСОК ЛИТЕРАТУРЫ}

1. Антощенко, А. В. Конфликт между Г. П. Федотовым и Правлением Свято-Сергиевского Православного института в Париже / А. В. Антощенко // Вестник РХГА. - 2014. - Т. 15, вып. 1. - С. 210-214.

2. Бычков, С. С. Георгий Петрович Федотов : (биографический очерк) / С. С. Бычков // Собр. соч. : в 12 т. / Федотов Г. П. - М. : Мартис, 1996. - Т. 1. - С. 5-50.

3. Бычков, С. С. Конфликт в Свято-Сергиевском Богословском институте (1939 г.) / С. С. Бычков // Собр. соч. : в 12 т. / Федотов Г. П. - М. : Sam \& Sam, 2008. -T. 12. - C. 262-378.

4. Бычков, С. С. Послесловие / С. С. Бычков // Собр. соч. : в 12 т. / Федотов Г. П. - М. : Sam \& Sam, 2008. - T. 12.- C. $464-482$.

5. Галямичева, А. А. Свобода слова в русской эмиграции: Конфликт профессора Г. П. Федотова с правлением Православного богословского института в Париже / А. А. Галямичева // Вестник Саратовского государственного социально-экономического университета. - 2008. - № 5 (24). - С. 131-133.

6. Георгиевский, Е. митр. Письмо митрополита Евлогия / Е. Георгиевский, митр. // Возрождение. $-1939 .-17$ февр. - № 4171. - С. 7.
7. К 110-летию Георгия Федотова. Документы и письма по поводу разногласия, возникшего между профессором Г. П. Федотовым и Правлением Богословского института в Париже / подгот. Д. Бон // Звезда. - 1996. - № 10. - С. 117-151.

8. Мень, А., прот. Возвращение к истокам / А. Мень, прот. // Святые Древней Руси / Федотов Г. П. - М. : Моск. рабочий, 1990. - С. 7-26.

9. Письма вокруг разногласий Г. П. Федотова с Богословским институтом / публ., подгот. текста и примеч. Т. В. Викторовой и Н. А. Струве // Вестник РХД. - 2002. - № 184 (2). - С. 186-222.

10. Поспеловский, Д. В. Русская православная Церковь в ХХ в. / Д. В. Поспеловский. - М. : Республика, 1995. $-511 \mathrm{c}$.

11. «Ради правды не пожалею ни зарубежной, ни русской церкви». Конфликт в Свято-Сергиевском институте в переписке Г.П. Федотова, 1939 г. / публ. подгот. С. С. Бычков // Исторический архив. -2003 . - № 1. - С. 73-86 ; № 3. - С. 63-87 ; № 4. - C. $73-116$.

12. Семенов, Ю. Ф. Ответ студентам Богословского института / Ю. Ф. Семенов // Возрождение. 1939. - 10 февр. - № 4170. - С. 3.

13. Семенов, Ю. Против «сатанинского нашествия» / Ю. Ф. Семенов // Возрождение. - 1939. 3 февр. - № 4169. - С. 1.

14. Семенов, Ю. Разгром большевиков и «сверх-христиане» / Ю. Ф. Семенов // Возрождение. $-1939 .-27$ янв. - № 4168. - С. 1.

15. Семенов, Ю. Роль газеты (Несколько вынужденных замечаний по поводу письма Владыки) / Ю. Ф. Семенов // Возрождение. - 1939. - 17 февр. №4171. - C. 7.

16. Федотова, Е. Георгий Петрович Федотов (1886-1951) / Е. Н. Федотова // Федотов Г. П. Лицо России. Статьи 1918-1930. - Париж : Ymca-Press, 1988. - C. I-XXXIV.

17. Яновский, В. С. Поля елисейские. Книга памяти / В. С. Яновский. - СПб. : Пушкинский фонд, 1997. $-277 \mathrm{c}$.

\section{REFERENCES}

1. Antoshchenko A.V. Konflikt mezhdu G. P. Fedotovym i Pravleniem Svyato-Sergievskogo Pravoslavnogo instituta v Parizhe [The Conflict between Georgy Fedotov and the Board of St. Sergius Orthodox Institute in Paris]. Vestnik RKhGA, 2014, vol. 15, fasc. 1, pp. 210-214.

2. Bychkov S.S. Georgiy Petrovich Fedotov: (biograficheskiy ocherk) [Georgy P. Fedotov: (Biographical Sketch)]. Fedotov G.P. Sobranie sochineniy v 12 t. [Collected Works in 12 vols.]. Moscow, Martis Publ., 1996, vol. 1, pp. 5-50. 
3. Bychkov S.S. Konflikt v Svyato-Sergievskom Bogoslovskom institute (1939 g.) [The Conflict in St. Sergius Theological Institute (1939)]. Fedotov G.P. Sobranie sochineniy v 12t. [Collected Works in 12 vols.]. Moscow, Sam \& Sam, 2008, vol. 12, pp. 262-378.

4. Bychkov S.S. Posleslovie [Afterword]. Fedotov G.P. Sobranie sochineniy v 12 t. [Collected Works in 12 vols.]. Moscow, Sam \& Sam, 2008, vol. 12, pp. 464-482.

5. Galyamicheva A.A. Svoboda slova v russkoy emigratsii: Konflikt professora G. P. Fedotova s pravleniem Pravoslavnogo bogoslovskogo instituta v Parizhe [Liberty of Speech in the Russian Emigration: Conflict of Professor Georgy Fedotov with the Board of St. Sergius Orthodox Institute in Paris]. Vestnik Saratovskogo gosudarstvennogo sotsialno-ekonomicheskogo universiteta, 2008, no. 5(24), pp. 131-133.

6. Georgievskiy, E. Pismo mitropolita Evlogiya [A Letter of Metropolitan Eulogy]. Vozrozhdenie, 1939, no. 4171 (Feb. 17), p. 7.

7. Bon D., ed. K 110-letiyu Georgiya Fedotova. Dokumenty i pisma po povodu raznoglasiya, voznikshego mezhdu professorom G. P. Fedotovym i Pravleniem Bogoslovskogo instituta v Parizhe [To the $110^{\text {th }}$ Anniversary of Georgy Fedotov. Documents and Letters about the Disagreement that Arose between Professor Georgy Fedotov and the Board of St. Sergius Orthodox Institute in Paris].Zvezda, 1996, no. 10, pp. 117-151.

8. Men A. Vozvrashchenie $\mathrm{k}$ istokam [Back to the Roots]. Fedotov G.P. Svyatye Drevney Rusi [Saints of Ancient Rus]. Moscow, Moskovskiy rabochiy Publ., 1990, pp. 7-26.

9. Viktorova T.V., Struve N.A., eds. Pisma vokrug raznoglasiy G. P. Fedotova s Bogoslovskim institutom [Letters about the Disagreements between Georgy Fedotov and the Theological Institute]. Vestnik RKhD, 2002, no. 184 (2), pp. 186-222.
10. Pospelovskiy D.V. Russkaya pravoslavnaya Tserkov $v X X v$. [Russian Orthodox Church in the $20^{\text {th }}$ Century]. Moscow, Respublika Publ., 1995. 511 p.

11. Bychkov S.S., ed. «Radi pravdy ne pozhaleyu ni zarubezhnoy, ni russkoy tserkvi». Konflikt v SvyatoSergievskom institute v perepiske G.P. Fedotova, 1939 g. (Publ. S. S. Bychkova) ["For the Sake of Truth I will Spare Neither the Russian Church Abroad, nor the Russian Church". The Conflict in the St. Sergius Theological Institute as Reflected in the Correspondence of G.P. Fedotov, 1939]. Istoricheskiy arkhiv, 2003, no. 1, pp. 73-86; no. 3, pp. 63-87; no. 4, pp. 73-116.

12. Semenov Yu.F. Otvet studentam Bogoslovskogo instituta [Response to Students of the Theological Institute]. Vozrozhdenie, 1939, no. 4170 (Feb. 10), p. 3.

13. Semenov Yu.F. Protiv «sataninskogo nashestviya» [Against the "Satanist Invasion"]. Vozrozhdenie, 1939, no. 4169 (Feb. 3), p. 1.

14. Semenov Yu.F. Razgrom bolshevikov i «sverkh-khristiane» [The Defeat of the Bolsheviks and the "Super-Christians"]. Vozrozhdenie, 1939, no. 4168 (Jan. 27), p. 1.

15. Semenov Yu.F. Rol gazety (Neskolko vynuzhdennykh zamechaniy po povodu pisma Vladyki) [The Role of the Newspaper (Some Constrained Comments on the Letter of the Metropolitan)]. Vozrozhdenie, 1939, no. 4171 (Feb. 17), p. 7.

16. Fedotova E.N Georgiy Petrovich Fedotov (1886-1951) [Georgy P. Fedotov (1886-1951)]. Fedotov G.P. Litso Rossii. Statyi 1918-1930 [The Face of Russia. Articles 1918-1930]. Paris, Ymca-Press, 1988, pp. I-XXXIV.

17. Yanovskiy V.S. Polya eliseyskie. Kniga pamyati [Champs Elysees. A Memory Book]. Saint Petersburg, Pushkinskiy fond, 1997.277 p.

\section{Information about the Author}

Anton A. Voytenko, Candidate of Sciences (History), Leading Researcher, Centre for Egyptological Studies, Russian Academy of Sciences, Prosp. Leninsky, 29, bld. 8, 119071 Moscow, Russian Federation, cesras@cesras.ru,http://orcid.org/0000-0002-3895-9909

\section{Информация об авторе}

Антон Анатольевич Войтенко, кандидат исторических наук, ведущий научный сотрудник Центра египтологических исследований, Российская академия наук, Ленинский просп., 29, стр. 8, 119071 г. Москва, Российская Федерация, cesras@cesras.ru, http://orcid.org/0000-0002-3895-9909 